Halaman: 78-84

\title{
Uji Daya Antelmintik Ekstrak Perasan dan Infusa Daun Srikaya (Annona squamosa L.) Terhadap Cacing Gelang Ayam (Ascaridia galli) Secara In Vitro
}

\author{
SUSI ENDRAWATI ${ }^{* 1}$, DAN WIYANA A. SAPUTRI ${ }^{2}$ \\ ${ }^{1}$ Laboratorium Farmakologi, Politeknik Kesehatan (POLTEKKES) Bhakti Mulia Sukoharjo, Jawa Tengah \\ ${ }^{2}$ Mahasiswa Program Studi Diploma III Farmasi Poltekkes Bhakti Mulia, Sukoharjo, Jawa Tengah \\ Diterima: 01 September 2015 - Disetujui: 26 Oktober 2015 \\ (C) 2015 Jurusan Biologi FMIPA Universitas Cenderawasih
}

\begin{abstract}
Srikaya (Annona squamosa L.) is a fruit that has been widely known to the people of Indonesia that have effective properties as traditional medicine. Srikaya seeds and leaves are known as a medicinal plant worm exterminator. This study aims to determine the anthelmintic influence of extract juice and srikaya leaf infused against roundworm of chicken in vitro, to determine the effect of concentration of extract juice and infuse of the srikaya leaf to the time of death of roundworm of chicken in vitro and to determine the most effective concentration of the extract juice and infuse of the srikaya leaf that has anthelmintic influence. This research is an experimental research design with Post test only controlled group design consisting of 150 of A. galli worms and were divided into 4 groups of treatments. Group 1 were put in $\mathrm{NaCl} 0.9$ \% liquid; group 2 was in srikaya leaves juice extract at a concentration of 25,50 , and $75 \mathrm{~g} / 100 \mathrm{ml}$; group 3 was in srikaya leaves infuse with a concentration of 25, 50, and 75 $\mathrm{g} / 100 \mathrm{ml}$, and group 4 was given $0.5 \%$ pyrantel pamoate liquid. Each treatments containing 5 worms in $25 \mathrm{ml}$ were done at 3 replication and incubated at $37^{\circ} \mathrm{C}$. The data were obtained from the observation of A. galli time of death every 15 minutes. The data were analyzed using One Way Anova test followed by the Post Hoc LSD test. There was an increasing of the death of A. galli correlating with the increase of the juice extract and infuse the srikaya leaf concentrations. The result showed there was a significant difference of $\mathrm{NaCl} 0.9 \%$ and pyrantel pamoate $0.5 \%$ treatments and there was no significant difference of the juice extract and infuse the srikaya leaf on worm death time. Extract juice and srikaya leaf infusion has anthelmintic influence against $A$. galli in vitro. The greater the concentration of the treatments, the greater anthelmintic influence visible on the death time acceleration of A. galli. Concentration of $75 \mathrm{~g} / 100 \mathrm{ml}$ is the most effective treatments of extract juice and srikaya leaf infusion but still lower than that of $0.4 \%$ pyrantel pamoate.
\end{abstract}

Key words: srikaya, A. squamosa, anthelmintic influence and A. galli.

\section{PENDAHULUAN}

Soil transmitted helmints (STH) merupakan infeksi cacing yang menyebabkan lebih dari 2 miliar orang telah terinfeksi, minimal oleh satu spesies STH serta menyebabkan masalah kesehatan

\footnotetext{
* Alamat korespondensi:

Prodi DIII Farmasi Poltekkes Bhakti Mulia, Jl. Raya SoloSukoharjo Km 09. Jawa Tengah. Telp./fax. +62271592577.

e-mail: susiendrawati5@gmail.com
}

secara luas (WHO, 2005). Pada umumnya cacing jarang menimbulkan penyakit serius, tetapi dapat menyebabkan gangguan kesehatan kronis. Cacing yang hidup berkembang di dalam saluran gastrointestinal sering ditemukan pada unggas. Terdapat pada kotoran, tanah tempat bermain, jari-jari kuku dan daging ayam yang kurang matang dimasak. Diperkirakan lebih dari $60 \%$ anak-anak di Indonesia menderita suatu infeksi cacing (Tjay \& Raharja, 2007). 
Cacingan merupakan parasit manusia maupun hewan yang sifatnya merugikan, merupakan hospes beberapa nematoda usus. Nematoda menyebabkan masalah kesehatan manusia. Terdapat jenis nematoda usus yang ditularkan melalui tanah disebut dengan "Soil Transmitted Helmints" yaitu Ascaris lumbricoides, Necator americanus, Ancylostoma duodenale, Trichuris trichiuria (Gandahusada et al., 1998). Fahrimal \& Raflesia (2002) berhasil mengidentifikasi tiga jenis nematoda yang ditemukan pada ayam kampung di Propinsi Aceh, yaitu Ascaridia galli, Heterakis gallinae dan Capillaria spp. Pada penelitian ini menggunakan cacing $A$. galli yang berkembang melalui kultur in vitro dalam lumen usus halus ayam kampung yang terinfeksi secara alami.

Data tahun 1994/1995 pada peternakan ayam di Denmark menunjukkan bahwa ayam dewasa terinfeksi cacing A. galli sebesar 63,8 \% (Permin, 1997). Data ini menunjukkan resiko terbesar terhadap infeksi cacing terdapat pada peternakan ayam dengan sistem dilepas dipekarangan, resiko yang besar juga terdapat pada sistem kandang litter yang dalam. Kejadian akut Ascaridiosis merupakan problema pada peternakan ayam, karena dapat menimbulkan kerugian yang besar (Akoso, 1993; Ghosh \& Singh, 1994). Korelasi positif antara populasi $A$. galli pada ayam dengan suhu, curah hujan dan kelembaban, menyebabkan jumlah cacing lebih banyak pada musim hujan, karena telur dapat berkembang pada lingkungan yang lembab (Kumari \& Thakur, 1999).

Antelmintik atau obat cacing berasal dari kata yunani yaitu yun yang artinya lawan, helmins yang artinya cacing. Antelmintik adalah obat yang dapat memusnahkan cacing dalam tubuh manusia dan hewan (Tjay \& Raharja, 2007). Antelmintik adalah obat yang digunakan untuk memberantas atau mengurangi cacing dalam lumen usus atau jaringan tubuh. Kebanyakan obat cacing diberikan secara oral, pada saat makan atau sesudah makan. Beberapa obat cacing perlu diberikan bersama dengan pencahar (Dirjen POM, 2007).

Masyarakat Indonesia sudah banyak yang telah mengenal dan menggunakan bahan baku alam sebagai obat tradisional, obat tradisional lebih murah dan mudah didapat, dibanding dengan obat dari sintesis atau zat kimia. Harga obat kimia relatif mahal dan mempunyai efek samping. Oleh karena itu pengobatan menggunakan obat tradisional semakin berkembang dengan memanfaatkan tanaman yang berada disekitar kita, salah satu tanaman yang berkhasiat sebagai antelmintik adalah srikaya.

Srikaya merupakan buah yang sudah banyak dikenal masyarakat, selain sebagai buah, daun srikaya juga dapat dimanfaatkan sebagai obat. Hampir seluruh bagian tanaman srikaya dapat di manfaatkan sebagai obat tradisional untuk menyembuhkan berbagai macam penyakit. Akar-nya dapat digunakan sebagai pencahar, biji untuk memacu pencernaan, obat cacing dan pembunuh serangga, sedangkan daunnya digunakan sebagai obat kudis, obat bisul dan obat cacing (Sudarsono et al., 2002).

Penelitian relevansi uji daya antelmintik secara in vitro menggunakan sampel cacing $A$. galli, dilakukan juga oleh Rony (2008), karena untuk mendapatkan cacing Ascaris lumbricoides cukup sulit, mengingat $A$. lumbricoides harus dikeluarkan dari tubuh penderita dalam keadaan hidup tanpa pengaruh obat cacing, selain itu cacing A. galli mempunyai kekerabatan dekat dengan $A$. lumbricoides dan cara infeksi yang sama yaitu telur yang inaktif tertelan melalui makanan. Pada infeksi berat pada ayam, akan terjadi enteritis dan hemoragi, sehingga menjadi anemia dan diare. Ayam terlihat kurang bugar, kurus dan lemah, serta produksi telur menurun (Soulsby, 1982). Tujuan penelitian ini untuk mengetahui daya antelmintik dari perasan dan infusa daun srikaya (A. squamosa). Hipotesis penelitian, diduga ekstrak perasan dan infusa daun srikaya (A. squamosa) dengan beberapa konsentrasi memiliki daya antelmintik terhadap cacing gelang ayam (A. galli).

\section{METODE PENELITIAN}

Penelitian dilakukan di Laboratorium Farmakognosi dan Laboratorium Farmakologi Program Studi DIII Farmasi Politeknik Kesehatan Bhakti Mulia Sukoharjo, pada bulan Februari-April 2015. 
Metode yang digunakan adalah eksperimen dengan desain post test only control group. Populasi penelitian ini adalah cacing $A$. galli yang diambil dari lumen usus ayam yang diperoleh dari tempat pemotongan ayam. Sampel penelitian yang digunakan sebanyak 150 ekor dengan kriteria inklusi yaitu cacing dewasa, aktif bergerak dengan ukuran 7-11 cm, tidak tampak cacat secara anatomi. Teknik sampling yang dipakai menggunakan teknik sampel random sampling terhadap cacing $A$. galli.

Sampel terbagi dalam 4 kelompok perlakuan yaitu kelompok 1 dimasukkan dalam larutan $\mathrm{NaCl}$ 0,9\% sebagai kontrol negatif. Kelompok 2 dimasukkan kedalam cawan yang berisi ekstrak perasan daun srikaya dengan konsentrasi 25, 50, dan 75 gram/100 ml. Kelompok 3 diberi infusa daun srikaya dengan konsentrasi 25, 50, dan 75 gram/100 ml. Kelompok 4 diberi larutan pirantel pamoat 0,5\% sebagai kontrol positif.

Prosedur penelitian, cawan petri disiapkan, masing-masing berisi $25 \mathrm{ml}$ ekstrak perasan daun srikaya dan $25 \mathrm{ml}$ infus daun srikaya. Masingmasing sediaan dengan konsentrasi 25, 50, dan 75

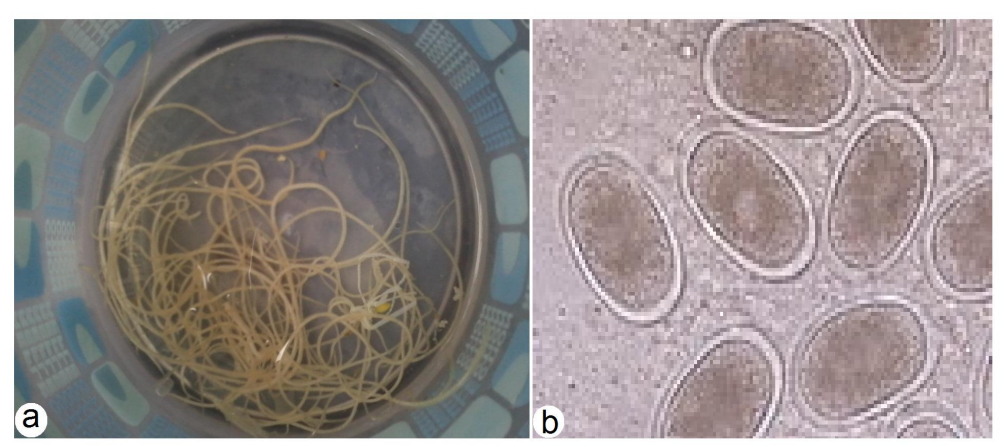

Gambar 1. Morfologi cacing gelang ayam (A. galli). a. cacing dewasa, dan b. telur cacing (tanpa skala).

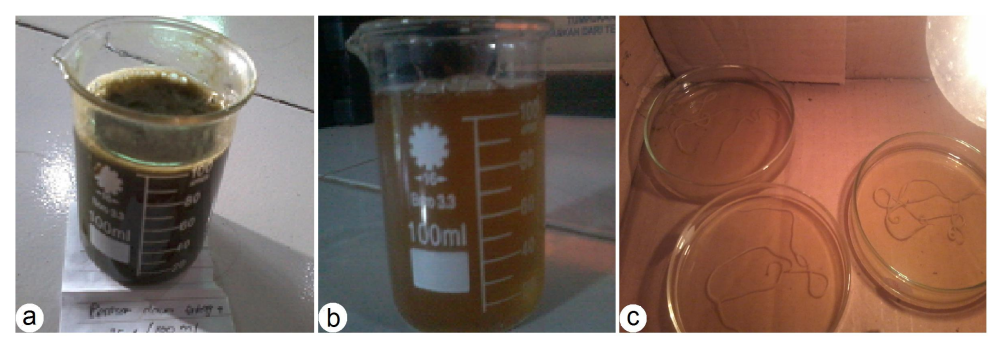

Gambar 2. Bahan ekstrak srikaya dan perlakuan pada cacing. a. ekstrak perasan daun srikaya, b. Infusa daun srikaya, c. cacing A. galli saat pengamatan. gram/100 ml, $25 \mathrm{ml}$ larutan pirantel pamoat 0,5\% serta $25 \mathrm{ml}$ larutan $\mathrm{NaCl}$ 0,9\%. Semua kelompok ini dihangatkan terlebih dahulu pada suhu $37^{\circ} \mathrm{C}$. Masing-masing cawan petri dimasukkan 5 ekor cacing A. galli yang masih aktif bergerak, kemudian diinkubasi pada suhu $37^{\circ} \mathrm{C}$ agar suhu lingkungan sesuai dengan suhu tubuh ayam. Pengamatan dilakukan setiap 15 menit sekali, dilihat apakah cacing mati, paralisis, atau masih normal setelah diinkubasi. Cacing-cacing tersebut diusik dengan batang pengaduk. Jika cacing diam pindahkan ke dalam air panas dengan suhu $50{ }^{\circ} \mathrm{C}$, apabila dengan cara ini tetap diam, berarti cacing tersebut telah mati, tetapi jika bergerak, berarti cacing ini hanya paralisis. Hasil yang diperoleh dicatat. Seluruh perlakuan dilakukan replikasi sebanyak 3 kali.

Data yang dikumpulkan pada penelitian ini adalah data primer yang didapat dari waktu kematian cacing $A$. galli pada masing-masing kelompok perlakuan. Data hasil pengamatan waktu kematian A. galli kemudian dianalisis dengan menggunakan uji one way anova dengan kepercayaan $99 \%$. Sebelum dilakukan uji one way anova sebagai syarat yang dipenuhi, yaitu data terdistibusi normal dan varians data homogen. Kemudian dilanjutkan dengan uji post hoc LSD untuk mengetahui letak perbedaan antar kelompok perlakuan. Data diolah dengan menggunakan SPSS 18.0 for windows. Hipotesis unutk uji One Way Anova, Ho: Ektrak perasan dan infusa daun srikaya tidak mempunyai pengaruh terhadap kematian cacing A. galli. H1: Ektrak perasan dan infusa daun srikaya mempunyai pengaruh terhadap kematian cacing $A$. galli. Jika nilai probabilitas $<0,01$, maka $\mathrm{H}_{0}$ ditolak. Jika nilai probabilitas $>$ 0,01, maka $\mathrm{H}_{0}$ diterima. Hipotesis untuk uji Post Hoc LSD, $\mathrm{H}_{0}$ : Waktu kematian cacing antara kelompok yang dibandingkan memiliki perbedaan yang tidak signifikan. $\mathrm{H}_{1}$ : Waktu kematian cacing antara kelompok yang dibandingkan memiliki perbedaan yang signifikan. Jika nilai probabilitas < 0,01, maka $\mathrm{H}_{0}$ ditolak. Jika nilai probabilitas $>0,01$, maka $\mathrm{H}_{0}$ diterima. 


\section{HASIL DAN PEMBAHASAN}

Hasil pengamatan organoleptis pada ekstrak perasan dan infusa daun srikaya (A. squamosa) diketahui bahwa terdapat perbedaan. Batasan waktu pengamatan percobaan uji daya antelmintik ekstrak perasan dan infusa daun srikaya ditetapkan dengan percobaan lama hidup cacing A. galli dalam larutan $\mathrm{NaCl} 0,9 \%$. Waktu yang diperoleh ditetapkan sebagai waktu maksimal pengamatan. Penentuan lama hidup cacing ditetapkan mulai dari saat cacing direndam dalam larutan $\mathrm{NaCl}$ 0,9 \% dan dimasukkan ke dalam inkubator $37^{\circ} \mathrm{C}$ sampai semua cacing dalam tiap rendaman mati diamati setiap 15 menit.

Uji pendahuluan pada penelitian ini berbeda dengan Arselyani (2002), untuk mengamati tanda kematian cacing dan menguji ketahanan hidup cacing diluar hospes, 8 ekor cacing direndam dalam larutan piperazine sitrat $0,5 \%$, sedangkan tanda-tanda kematian cacing dilakukan dengan membandingkan aktivitas dan kondisi morfologis (bentuk dan warna) antara cacing yang hidup dan cacing yang mati. Hasil pengamatan diperoleh waktu kelangsungan hidup cacing $A$. galli dalam larutan $\mathrm{NaCl}$ 0,9\% dengan replikasi sebanyak 3 kali adalah selama 2010 menit, atau 33 jam lebih 30 menit. Sehingga waktu pengamatan percobaan uji daya antelmintik ekstrak perasan dan infusa daun srikaya ( $A$. squamosa) dilakukan dengan jangka waktu pengamatan maksimal selama 2010 menit atau 33 jam lebih 30 menit. Hasil penelitian tersebut sedikit berbeda dengan penelitian Arif, A (2008), yaitu pada larutan NaCL 0,9 \% memperoleh waktu kelangsungan hidup cacing $A$. galli sebanyak 8 cacing selama 45 jam.

Pada penelitian ini, pengamatan dilakukan dengan mengamati waktu kematian cacing A. galli pada masing-masing kelompok perlakuan yaitu pada larutan $\mathrm{NaCl}$ 0,9 \% sebagai kontrol negatif, pirantel pamoat 0,5\% sebagai kontrol positif, ekstrak perasan dan infusa daun srikaya dengan masing-masing konsentrasi sebesar 25, 50 dan 75 $\mathrm{g} / 100 \mathrm{ml}$ (Tabel 2).

Hasil penelitian (Tabel 2) menunjukkan bahwa rerata waktu kematian cacing pada kelompok ekstrak perasan daun srikaya $25 \mathrm{~g} / 100$ $\mathrm{ml}$ adalah 1465 menit, ekstrak perasan daun srikaya $50 \mathrm{~g} / 100 \mathrm{ml}$ adalah 1320 menit, ekstrak perasan daun srikaya $75 \mathrm{~g} / 100 \mathrm{ml}$ adalah 1270 menit, sedangkan rerata waktu kematian pada infusa daun srikaya $25 \mathrm{~g} / 100 \mathrm{ml}$ adalah 1460 menit, infusa daun srikaya $50 \mathrm{~g} / 100 \mathrm{ml}$ adalah 1290 menit dan infusa daun srikaya 75 g/100 ml adalah 1240 menit. Pada kelompok kontrol positif menggunakan pirantel pamoat dengan konsentrasi $0,5 \%$ didapat rerata waktu kematian cacing adalah 450 menit, sedangkan pada $\mathrm{NaCl}$ 0,9\%

Tabel 1. Hasil organoleptis ekstrak perasan dan infusa daun srikaya (A. squamosa).

\begin{tabular}{lll}
\hline Organoleptis & ekstrak perasan daun srikaya & infusa daun srikaya \\
\hline bentuk & larutan kental & larutan jernih \\
warna & hijau tua & kuning kecoklatan \\
bau & khas daun srikaya & khas daun srikaya \\
rasa & pahit & pahit \\
\hline
\end{tabular}

Tabel 2. Waktu kematian (menit) cacing A. galli pada masing-masing kelompok perlakuan.

\begin{tabular}{|c|c|c|c|c|c|c|c|c|}
\hline \multirow[t]{3}{*}{ Replikasi } & \multicolumn{8}{|c|}{ Waktu kematian cacing (menit) } \\
\hline & \multirow{2}{*}{$\begin{array}{l}\mathrm{NaCl} \\
0,9 \%\end{array}$} & \multicolumn{3}{|c|}{$\begin{array}{l}\text { ekstrak perasan daun srikaya } \\
(\mathrm{g} / 100 \mathrm{ml})\end{array}$} & \multicolumn{3}{|c|}{$\begin{array}{c}\text { infusa daun srikaya } \\
(\mathrm{g} / 100 \mathrm{ml})\end{array}$} & \multirow{2}{*}{$\begin{array}{c}\text { pirante } \\
\text { pamoat } \\
0,5 \%\end{array}$} \\
\hline & & 25 & $\frac{g / 100}{50}$ & 75 & 25 & $\frac{1100 \mathrm{r}}{50}$ & 75 & \\
\hline I & 1950 & 1485 & 1380 & 1200 & 1440 & 1290 & 1215 & 465 \\
\hline II & 2010 & 1455 & 1335 & 1290 & 1470 & 1305 & 1245 & 480 \\
\hline III & 1995 & 1455 & 1245 & 1320 & 1470 & 1275 & 1260 & 405 \\
\hline Rerata & 1985 & 1465 & 1320 & 1270 & 1460 & 1290 & 1240 & 450 \\
\hline
\end{tabular}


diperoleh rerata waktu kematian cacing adalah 1985 menit. Hasil rerata waktu pada kelompok perendaman pirantel pamoat merupakan hasil rerata waktu kematian cacing $A$. galli yang paling cepat dan memiliki efek antelmintik terkuat, semakin besar konsentrasi ekstrak perasan dan infusa daun srikaya maka semakin besar efek antelmintik.

Pendapat tersebut dikuatkan oleh Reza (2010) bahwa efek antelmintik pirantel pamoat lebih kuat dibandingkan dengan efek infusa daun alpukat mulai dari konsentrasi $20 \%$ sampai dengan konsentrasi $100 \%$, karena pirantel pamoat bekerja menghambat enzim kolinesterase yang menyebabkan penumpukkan asetilkolin sehingga otot cacing mengalami hiperkontraksi. Hal ini menunjukkan bahwa ekstrak perasan dan infusa daun srikaya mempunyai daya antelmintik lebih lemah jika dibandingkan dengan pirantel pamoat. Jika dilihat dari waktu kematian cacing pada penelitian Aribawa et al,(2008), modifikasi metode rendaman dari Lamson dan Brown, ekstrak etanol daun mengkudu konsentrasi $50 \mathrm{mg} / \mathrm{ml}$ mempunyai rata-rata waktu kematian semua cacing cepat, dibandingkan dengan konsentrasi 20, 30, dan 40 $\mathrm{mg} / \mathrm{ml}$.

Hasil uji One-Sample Kolmogorow Smirnov Test diketahui nilai probabilitas (p) pada semua

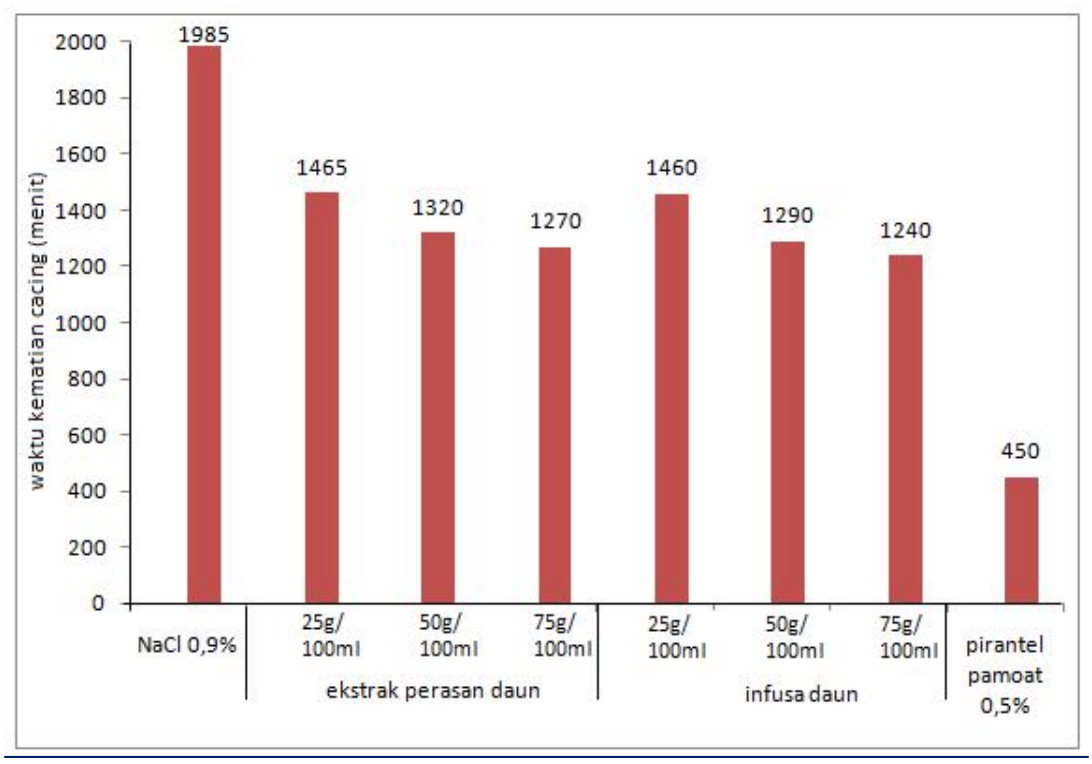

$\overline{\text { Gambar 3. Waktu kematian cacing pada masing-masing kelompok }}$ perlakuan. kelompok perlakuan 0,064 >0,01 yang berarti bahwa data tersebut terdistribusi normal, sedangkan pada tes homogenitas varians didapatkan nilai probabilitas (p) 0,55>0,01, yang berarti varians data homogen. Pada uji one way anova didapatkan nilai probabilitas (p) 0,000 < 0,01 yang berarti terdapat pengaruh ekstrak perasan dan infusa daun srikaya terhadap kematian cacing $A$. galli dan ada perbedaan yang signifikan pada keempat kelompok perlakuan.

Analisis dilanjutkan dengan uji Post Hoc LSD, perlakuan pada sampel bahan uji adalah sebagai berikut; $\mathrm{NaCl}$ sebagai kontrol negatif (a), pirantel pamoat sebagai kontrol positif (b), ekstrak perasan daun srikaya $25 \mathrm{~g} / 100 \mathrm{ml}$ (c), ekstrak perasan daun srikaya $50 \mathrm{~g} / 100 \mathrm{ml}(\mathrm{d})$, ekstrak perasan daun srikaya $75 \mathrm{~g} / 100 \mathrm{ml}(\mathrm{e})$, infusa daun srikaya $25 \mathrm{~g} / 100 \mathrm{ml}(\mathrm{f})$, infusa daun srikaya $50 \mathrm{~g} / 100 \mathrm{ml}$ (g), infusa daun srikaya $75 \mathrm{~g} / 100 \mathrm{ml}(\mathrm{h})$. Dari uji Post Hoc LSD menunjukkan ada beda signifikan antara perlakuan, ab, ac, ad, ae, af, ag, ah, bc, bd, be, bf, bg, bh, cb, cd, ce, cg, ch,ef dan fg. Sedangkan antara perlakukan cf, de, df, dg, dh, eg, eh, dan hg, menunjukkan tidak ada beda signifikan antara perlakuan.

Hasil uji Post Hoc LSD menyatakan bahwa perbandingan waktu kematian cacing antara kelompok perlakuan $\mathrm{NaCl} 0,9 \%$ dan pirantel pamoat $0,5 \%$ dengan semua perlakuan memiliki nilai probabilitas (p) $0,000<0,01$, yang berarti bahwa waktu kematian cacing antar kelompok tersebut memiliki perbedaan yang signifikan. Pirantel pamoat memiliki efek samping berupa gangguan pencernaan dan sakit kepala, sedangkan khasiat dari daun srikaya digunakan untuk mengobati gangguan pencernaan seperti diare dan disentri, sehingga dapat dikatakan bahwa ekstrak perasan dan infusa daun srikaya tidak mempunyai efek samping seperti pirantel pamoat. Ekstrak perasan dan infusa daun srikaya mempunyai kelebihan yaitu murah dan cara pembuatannya mudah. 
Dengan kelebihan yang dimiliki, ekstrak perasan dan infusa daun srikaya mempunyai potensi untuk dikembangkan sebagai alternatif obat dalam pengobatan penyakit $A$. scariasis.

Menurut penelitian Balqis et al. (2009), pada perkembangan telur infektif $A$. galli melalui kultur in vitro, kemampuan menghasilkan telur setiap ekor cacing $A$. galli betina dewasa bervariasi antara 4.000 sampai 10.000 butir, keberhasilan telur berkembang menjadi telur infektif secara in vitro adalah $89,46 \%$. Perkembangan hidup cacing yang begitu pesat. Dalam penelitiannya, Vicente $e t$ al. (2011) mengukur infeksi STH berdasarkan penentuan hemoglobin dan indikator status gizi anak-anak, 34,10\% anak-anak sekolah memiliki setidaknya satu infeksi STH, sedangkan 5,90 \% memiliki intensitas infeksi berat. 8,30 \% memilki kadar hemoglobin di bawah normal.

Hasil penelitian ini menunjukkan efek antelmintik infusa daun srikaya lebih efektif dibandingkan dengan ekstrak perasan daun srikaya, bila dilihat dari pembuatan, bahan uji infusa lebih steril dibandingkan dengan ekstrak perasan daun srikaya. Pembuatan dilakukan dengan cara perebusan selama 15 menit pada suhu $90{ }^{\circ} \mathrm{C}$ sehingga dapat mematikan mikroorganisme yang mengganggu, dan selama proses perebusan mengeluarkan zat aktif dari dalam daun tersebut. Semakin besar konsentrasinya bahan aktif, efeknya akan semakin lebih besar. Nurdjanah \& Perwitasari (2004) berpendapat, semakin besar konsentrasi infus biji srikaya, antara kadar (100\% b/v, 75 \% b/v, 50 \% b/v, 25 $\%$ b/v dan $5 \%$ b/v), aktivitas antelmintik akan semakin besar.

\section{KESIMPULAN}

Ekstrak perasan daun dan infusa daun srikaya memiliki daya antelmintik terhadap cacing A. galli secara in vitro. Infusa daun srikaya lebih efektif dibandingkan dengan ekstrak perasan daun srikaya. Semakin besar konsentrasi ekstrak perasan dan infusa daun srikaya semakin besar efek antelmintik terlihat dari percepatan rerata waktu kematian cacing $A$. galli. Konsentrasi ekstrak perasan dan infusa daun srikaya pada konsentrasi $75 \mathrm{~g} / 100 \mathrm{ml}$ memiliki konsentrasi yang lebih efektif, dibandingkan konsentrasi 25 dan $50 \mathrm{~g} / 100 \mathrm{ml}$, namun konsentrasi konsentrasi tersebut masih rendah bila dibandingkan dengan pirantel pamoat $0,5 \%$.

\section{DAFTAR PUSTAKA}

Akoso, B.T. 1993. Manual kesehatan unggas bagi petugas teknis penyuluh dan peternak. Penerbit Kanisius, Yogyakarta.

Aribawa, R., A. Wihdayati, dan Mustofa. 2008. Daya Antelmintik ekstrak etanol daun mengkudu (Morinda citrifolia L.) terhadap cacing Ascaridia galli secara in vitro dan profil KLT-nya. Jurnal Ilmu Farmasi dan Farmasi Klinik. 5(2): 11-28.

Arif, A. 2008. Uji daya antelmintik infus biji dan infus daun petai cina (Leucanea leucocephala) terhadap cacing gelang ayam (Ascaridia gall) secara in vitro. [KTI]. Universitas Diponegoro, Semarang.

Arselyani, E.M. 2002. Daya antelmintik infusa daun sirsak (Annona muricata L.) terhadap Ascaridia galli secara in vitro. [Skripsi]. Fakultas Farmasi Universitas Sanata Dharma, Yogyakarta.

Balqis, U., Darmawi, M. Hambal, dan R. Tiuria. 2009. Perkembangan telur infektif Ascaridia galli melalui kultur in vitro. Jurnal Med. Vet. 3(2): 227-233.

Dirjen POM. 2007. Farmakologi dan terapi. FKUI, Jakarta.

Fahrimal, Y., dan R. Raflesia. 2002. Derajat infestasi nematoda gastrointestinal pada ayam buras yang dipelihara secara semi intensif dan tradisional. Jurnal Med. Vet. 2(2): 114118.

Gandahusada, S., dan D.I. Henry, dan P. Wita. 1998. Parasitologi Kedokteran. Edisi ketiga. Gaya Baru, Jakarta.

Ghosh, J.D. and J. Singh. 1994. Acute Ascaridiosis in Chickens. A Report. Indian Veterinary Journal. 717-719.

Kumari, R. And S. Thakur. 1999. Infection pattern of nematode Ascaridia galli in Gallus gallus domesticus. J. Ecobiol. 11: 277-283.

Nurdjanah dan Perwitasari. 2004. Aktivitas antelmintik infusa biji srikaya (Annona squamosa Linn) terhadap Ascaridia galli Schrank secara in vitro. Jurnal Ilmu Farmasi. 2(2): 77-83.

Permin, A. 1997. Helminths and helminthosis in poultry with special emphasis on Ascaridia galli in chickens. [Ph.D Thesis] The Royal Veterinary and Agricultural Uni-versity, Copenhagen, Denmark.

Reza, H.P. 2010. Pengaruh infusa alpukat (Persea americana, Mill) terhadap waktu kematian cacing Ascaris summ, Goeze in vitro. [Skripsi]. Universitas Sebelas Maret, Surakarta.

Rony, K. 2008. Uji daya antelmintik infus daun dan infus biji pare (Momordica charantia) terhadap cacing gelang ayam (Ascaridia galli) secara in vitro. [KTI]. Universitas Diponegoro, Semarang. 
Soulsby, E.J.L. 1982. Helminths, arthropods and protozoa of domesticated animals. 7th Ed. Bailiere, Tindall, London.

Sudarsono, P., D. Gunawan, S. Wahyuono, dan I.A. Donatus. 2002. Tumbuhan Obat II. Universitas Gadjah Mada, Yogyakarta.

Tjay, T.H., dan K. Raharja. 2007. Obat-obat penting khasiat, penggunaan dan efek-efek sampingnya. Edisi keenam. PT Elex Media Komputindo Kelompok Gramedia, Jakarta.
Vicente, Y.B., F.I.G. Totanes, W.U. de Leon, Y.F. Lumampao, R. Nadine, T. Ciro. 2011. Soil-transmitted helminth and other intestinal parasitic infections among school children in indigenous people communities in Davao del Norte, Philippines. Journal Acta Tropica. 12: S12-S18.

WHO. 2005. The millennium development goals.(http://apps. who.int/iris/bitstream/10665/68876/1/WHO_CDS_CPE_PV C_2005.12pdf. 